

Andrzej Kominek

DOI: 10.33896/PorJ.2021.1.1

(Uniwersytet Jana Kochanowskiego, Kielce,

e-mail: jedruskom@poczta.onet.pl)

ORCID: 0000-0003-4734-1796

\section{BEZMYŚLNY JĘZYK. ZAKŁÓCENIA ZJAWISK POZNAWCZYCH U OSÓB Z AUTYZMEM}

\section{WPROWADZENIE}

Wśród wielu sądów o języku ten wydaje się najlogiczniejszy i oczywisty, że silny wpływ na posługiwanie się językiem maja procesy poznawcze. Podkreślają go przykładowe wypowiedzi „ludzi słowa”: ${ }^{1}$

Znaczenie nie tylko jest nieustannie tworzone, jest też kluczowe. Używamy języka, żeby nadać światu sens [Bergen 2018, 14];

Potrzebujemy słów, jeśli chcemy wiedzieć. Prócz słów, jakie mamy inne możliwości, żeby wejrzeć w siebie, zrozumieć innych, wyobrazić sobie świat? [Myśliwski 2018, $112]$

Język (...) stwarza sobie człowieka, by ten nie mógł się bez niego obejść, by się w nim rozgościł jak u siebie w domu, by przeżył w nim rozumnie swoje życie [Termińska 1991, 65].

Cytowani myśliciele nie mówia natomiast nic o samych procesach poznawczych, takich jak np.: kategoryzowanie, językowy obraz świata, tworzenie znaczeń przenośnych, znajomość określonych ram i scen kulturowych czy posługiwanie się takimi umiejętnościami jak używanie języka do podtrzymania kontaktu i mówienie o nim samym itp.

Przyjrzyjmy się następującej scenie. Co byście pomyśleli, gdybyście nagle na spacerze poczuli na swoich „plecach” kogoś, kto szedłby pół kroku za wami, usiłując was wyminąć, i usłyszelibyście kilkakrotnie powtórzony tekst: „Halo! Z uczuciem!”. Czy to samo, co ja? Pomyślałbym, że ten ktoś sobie żartuje, próbujac zmusić mnie do szybszego tempa. No bo chyba nie byłby aż taki bezpośredni, poganiajac mnie w nieco nieelegancki, a nawet agresywny sposób. Wnioskuję to na podstawie

${ }^{1}$ Bez względu na sposób myślenia o języku, punkt widzenia i profil poznawczy: gdy chodzi o znakomitego powieściopisarza (Wiesław Myśliwski), neurokognitywistę (Benjamin K. Bergen) czy lingwistę (Kamilla Termińska). 
całej tej sytuacji, bo tylko taka interpretacja wydaje mi się sensowna i racjonalna. Chociaż pewnie stwierdzicie to samo co ja, że pozostaje ona jednak dziwna i można jej racjonalność umieścić jedynie na granicy dopuszczalnej grzeczności. Co sprawia zatem, że osoba wypowiadająca ten tekst uznaje go za akceptowalny w danej sytuacji? Skad wie, że jej ryzykowne zachowanie nie zostanie odczytane jako agresja i zbytnie spoufalenie się $z$ odbiorca, którego ta osoba przecież nie zna? Pora uchylić rabka tajemnicy. Aby doszło do komunikacji w pełni intencjonalnej między obiema stronami tego aktu, zarówno nadawca, jak i odbiorca musza rozumieć intencje, myśli i przekonania drugiej ze stron. W tym wypadku do takiej komunikacji nie dochodzi, ponieważ nadawca nie bierze w ogóle pod uwagę tego, co pomyśli odbiorca.

Opisana osoba nie ma podstawowej umiejętności poznawczej, jaka jest świadomość swoich i cudzych aktów mentalnych. Wiedza, która odnosi się do tego rodzaju umiejętności, mówi o tym, że osoby neurotypowe $^{2}$ mają zazwyczaj tzw. teorię umysłu, to znaczy, że „przypisują stany umysłowe sobie i innym". ${ }^{3}$ Alan Leslie tłumaczy to w ten sposób, że maja one mózgi, które sa w stanie tworzyć kopie czy też reprezentacje ludzi, przedmiotów i zdarzeń. Reprezentacje „wprowadzaja” świat do umysłu. Oprócz kopii rzeczywistości umysł ludzi neurotypowych tworzy reprezentacje tego, co inni ludzie zamierzają zakomunikować. Umysł posiada mechanizm „odłączania” tych reprezentacji od rzeczywistości. Sa one połaczone $z$ pragnieniami, myślami czy wspomnieniami innej osoby. Po odłączeniu te nowe reprezentacje same stają się przedmiotem myślenia i gry wyobraźni. Zdolność ta nazywana jest mentalizowaniem (mentalizing), czyli przewidywaniem związków między zewnętrznymi stanami rzeczy a wewnętrznymi stanami umysłu. ${ }^{4} \mathrm{~W}$ świetle teorii umysłu mamy do czynienia $z$ przekonaniami tzw. drugiego rzędu. Przekonania pierwszego rzędu odnoszą się do myślenia przypadkowego i behawioralnego (np. 'Michał myśli, że Zosia ma urodziny' - widzi bowiem tort, świeczki i Zosię, która zdmuchuje świeczki) i leżą w kompetencji osoby opisanej przeze mnie. Ale przekonania drugiego rzędu wymagaja zdolności do myślenia o myśleniu, a także rozpoznawania motywów i intencji innych ludzi,

${ }^{2}$ Osoby w normie rozwojowej określa się mianem neurotypowych, typowych lub prawidłowo rozwijajacych się. Ponieważ wyrażenia te sa zabarwione dodatnio w porównaniu $z$ sugerowanymi osobami "gorszymi” (nieneurotypowymi), coraz częściej w kręgach osób zaangażowanych w różnego rodzaju działania na rzecz równego traktowania tych osób mówi się o neuroróżnorodności, dążąc do wyeliminowania pojęcia normy w tym zakresie. Termin neuroróżnorodność wymyśliła rzekomo w swojej pracy dyplomowej australijska studentka antropologii i socjologii Judy Singer pod koniec lat dziewięćdziesiątych XX wieku; zob. Silberman 2017, 437.

3 To pierwsza, najprostsza definicja teorii umysłu z 1978 r. autorstwa Davida Premacka i Guya Woodruffa [cyt. za: Frith 2008, 109].

4 Referuje za: U. Frith [2008, 105-109]. 
np. 'Michał myśli, że Zosia myśli, że on jest na nią zły' [Winczura 2008, 53]. Teoria umysłu umożliwia nam więc dekodowanie wiedzy utrwalonej w języku oraz posługiwanie się nią.

Okazuje się, że do osób ignorujących tę wiedzę (nie $z$ własnej woli) należą $z$ cała pewnością osoby $z$ autyzmem. Nie mają one (w ogóle albo wystarczającej) teorii umysłu, czego konsekwencją sa zaburzenia w przyswajaniu sobie językowego obrazu świata, nieumiejętność dekodowania znaczeń przenośnych, nieużywanie języka do podtrzymania kontaktu i niemówienie o samym języku, a także wiele innych. W artykule tym postanowiłem wskazać te cechy języka osób $z$ autyzmem, o których niewystarczająco albo w ogóle się nie mówi w ważnych opracowaniach dotyczących kompetencji językowej i komunikacyjnej, które swoje źródło mają w zaburzeniach procesów poznawczych u tych osób. ${ }^{5}$

\section{JĘZYK JAKO IDIOLEKT I IDIOLEKTALNY OBRAZ ŚWIATA}

Normalnie w języku osób neurotypowych przechodzimy $z$ jednego kodu na drugi. Możemy myśleć i mówić prywatnie, czuć się rodzinnie, identyfikując się z bliskimi za pomoca „czułych słówek”, iść na mecz, by poczuć tożsamość z grupa zaprzyjaźnionych kibiców, czy udawać się do swojej korporacyjnej pracy, słuchając całkiem innych słów obcego świata. Wszędzie tam przełączamy się na określony socjolekt, zachowujac jednak - zgodnie ze współczesnym rozumieniem - cechy swojego indywidualnego, osobniczego języka, zwanego najczęściej idiolektem. ${ }^{6} \mathrm{Za}$ każdym razem dostosowujemy się do wymaganej roli. ${ }^{7}$

5 Za pierwszą w kolejności cechę uważam charakterystyczny dla osób z autyzmem idiolektalny obraz świata. Ponieważ sam się tym zjawiskiem nie zajmowałem, wykorzystuję badania Joanny Antczak-Sokołowskiej [2017] i Marty Korendo [2013]. Pozostałe zagadnienia były przedmiotem moich przemyśleń we wcześniejszych publikacjach (zob. Bibliografia).

6 Jedna $z$ najnowszych definicji idiolektu proponuje Anna Kozłowska, która próbuje umiejscowić go wśród innych zjawisk mowy i postrzega jako całość językowej kompetencji jednostki mówiącej, czyli ogół wiedzy i umiejętności, które pozwalaja jej konstruować wypowiedzi. Kompetencja ta jest indywidualna adaptacja (bo niekoniecznie przetworzeniem) języka ogólnego, a zarazem podstawowym wymiarem jego istnienia i funkcjonowania. Tak określony idiolekt różni się od języka ogólnego, a także wszelkich jego odmian (terytorialnych, środowiskowych, społecznych, funkcjonalnych i in.) jednostkowościa swego nosiciela; od tekstu abstrakcyjnościa czy potencjalnością [Kozłowska 2009, 119-120].

7 Posługiwanie się językiem nawet w całkiem oryginalny sposób ma służyć komunikacji. Nie ma takiej rzeczy jak własność prywatna w języku. Przechodzimy z jednego kodu na drugi, by tak naprawdę utrafić w słownik tego drugiego: członka rodziny, towarzysza wspólnych emocji w grupie kibiców sportowych czy kolegi pracującego w tej samej firmie, mającej określony profil i zwyczaje. Idiolekt jest w tym znaczeniu „dość nienaturalną fikcją" [Jakobson 1989a, 162]. 
Dla cierpiącego natomiast na afazję lub na autyzm, który stracił taką zdolność, jego „idiolekt” staje się zdeterminowana biologicznie jedyną rzeczywistościa językowa [por. Jakobson 1989a, 162]. Choćby osoby te chciały odgrywać wymagane społecznie role, wypowiedzi innych pozostaną dla nich bezsensownym żargonem albo tekstem ułożonym w nieznanym im języku.

Jedna $z$ metod badania idiolektu jest teoria językowego obrazu świata, która tłumaczy tzw. idiolektalny obraz świata charakterystyczny dla subiektywnego wariantu wiedzy o świecie. Tak jak idiolekt jest dla autyka jedyną rzeczywistościa językowa, tak jego idiolektalny obraz świata jest jedynym oryginalnym modelem rzeczywistości utrwalonej w języku. Chciałbym pokazać, na czym polega to zjawisko poznawcze, opierajac się na badaniach Joanny Antczak-Sokołowskiej [2017]. Zgodnie $z$ definicją Jerzego Bartmińskiego językowy obraz świata to zespół sądów o świecie utrwalony w leksyce oraz $\mathrm{w}$ formach gramatycznych języka [Bartmiński 2012, 12-13]. J. Antczak-Sokołowska otrzymała ciekawe wyniki, badajac językowy obraz kota, psa i konia u szesnastoletniego chłopca $z$ autyzmem. Badaczka posłużyła się fasetowa metodą eksplikowania haseł, wyróżniając: 'kategorię', 'środowisko', 'rozmiar', 'wygląd', 'zachowanie', 'stosunek do człowieka'. Okazało się, że chłopiec ten $z$ wieloma fasetami miał problemy charakteryzujace się głównie wiedzą niepełną lub fragmentaryczna, np. na pytanie Jak wyglada kot, pies, koń? najczęstszą odpowiedzią było, że są fajne. Wiele pytań związanych $z$ wiedza o tych zwierzętach okazało się za trudnych. Chłopiec nie rozróżniał poziomu metaforycznego i dosłownego $\mathrm{w}$ wyrażeniach $\mathrm{z}$ nazwami zwierząt. Na podstawie przeprowadzonych testów i rozmowy $z$ badanym autykiem autorka doszła do wniosków, które oczywiście należałoby zweryfikować na odpowiedniej próbie badawczej, że w jego umyśle istnieje kolekcja konkretnych sytuacji związanych z pewnymi doświadczeniami i że tworzą one jakąś całość, ale zupełnie inną niż modele istniejące w języku ogólnym.

Ta inność, nieprzystawalność obrazów jest bardzo wyraźna - konkluduje Antczak-Sokołowska - gdy zaczynamy się poruszać w takich obszarach języka jak: słowotwórstwo, frazeologia, konotacje i asocjacje, metaforyka [Antczak-Sokołowska 2017, 13].

Spostrzeżenia te potwierdziła również w swoich badaniach Marta Korendo, wykazując na przykładzie wypowiedzi osób z zespołem Aspergera modyfikacje w języku tych osób: brak słownictwa w określonych polach semantycznych (brak nazw emocji, jednostek czasu, nazw smaków i zapachów), ${ }^{8}$ duże trudności w językowym rozumieniu i wyraża-

8 Zjawiskiem przeciwstawnym jest zjawisko, które M. Korendo nazywa powstawaniem tzw. kominów słownikowych, czyli nadmierne rozbudowywanie słownictwa zwiazanego z wybranym polem semantycznym [Korendo 2013, 119-120]. Por.: Szatmari 2007; Silberman 2017. Dodatkowym wyróżnikiem takiego hob- 
niu wszelkiego typu relacji (pokrewieństwa, przyczynowo-skutkowych, gradualnych itp.), brak profilowania (co wiazze się z cząstkowym, zatomizowanym sposobem widzenia świata), brak rozumienia odpowiedniej dla wszelkiego rodzaju kontaktów kompetencji społecznej i sytuacyjnej, trudności związane $z$ brakiem kompetencji kulturowej (w zakresie np. form grzecznościowych), duży udział w wypowiedziach cytatów, zwrotów gotowych, schematycznych [Korendo 2013, 157].

Niektóre $z$ wymienionych cech idiolektalnego obrazu świata autyków stanowia podstawę innych zjawisk poznawczych, które przedstawię w dalszym ciagu tego artykułu.

\section{AUTOSTYMULACYJNA FUNKCJA JĘZYKA}

Według Romana Jakobsona sytuację komunikatywną określa sześć funkcji językowych. Wypowiedź może być zorientowana na treść denotacyjna (funkcja poznawcza), na nadawcę (funkcja emotywna), odbiorcę (funkcja konatywna), następnie na sam komunikat (funkcja poetycka), podtrzymywanie kontaktu (funkcja fatyczna) i na sam kod (funkcja metajęzykowa) [Jakobson 1989b, 77-124]. Sam Jakobson mówi o wyróżnionych w jego schemacie sześciu funkcjach jako elementach aktu komunikacji, ponieważ w każdej z nich jest realizowana w określony sposób nadrzędna funkcja, która możemy nazwać komunikacyjną. Podobnie uważają inni językoznawcy, że zarówno sposób prezentacji rzeczywistości (funkcja poetycka), jak i podtrzymywanie relacji między uczestnikami komunikacji (funkcja fatyczna) oraz zwrócenie uwagi na język sposobu przekazu (funkcja metajęzykowa), w formie zamierzonej bądź niezamierzonej, opierają się na mówieniu o jakiejś rzeczywistości: pozajęzykowej, wewnatrzjęzykowej i sytuacyjnej. Jak pisze Robin Dunbar, ,język wyewoluował, by umożliwić ludziom wymianę informacji" [Dunbar 2014, 142]. Oprócz funkcji informacyjnej centralne miejsca zajmuja funkcje społeczne: podtrzymywanie więzi społecznych (funkcja fatyczna), wywieranie wpływu na innych (funkcja konatywna, zwana przez językoznawców perswazyjna) i inne [por. m.in.: Aitchison 2002, 30-42; Everett 2019, 234-235; 369-370; Malinowski 1987; Dunbar 2017, 170; 194].

Jak wynika $z$ wielu badań, głównie w świetle teorii umysłu, język realizujący w pełni funkcję komunikacyjna nie stanowi istoty języka autyków. Jest to częściowo lub w pełni mowa nieautonomiczna, kopiowana, nieintencjonalna, począwszy od wysokofunkcjonujacychch osób z zespołem Aspergera, a skończywszy na autykach niskofunkcjonujących. Nazywam

bystycznego „dyskursu” osób z ASD jest subiektywna interpretacja nazywanych zjawisk, odbijajacca się w swoistej kategoryzacji, a także percepcji i poznawaniu obiektów zainteresowania, co ciekawie opisał np. Jorge Luis Borges w opowiadaniu Pamiętliwy Funes [1972]. 
ja w szerszym znaczeniu „mówieniem za kimś”, łączacym echolalię ze stereotypowym, niekiedy rytualnym natręctwem językowym. „Mówienie za kimś" polega na bezrefleksyjnym naśladownictwie mowy, tzn. bezpośrednim lub odroczonym powtarzaniu $z$ podobna intonacją, w sposób mimowolny i automatyczny dźwięków, wyrazów, całych zdań, a nawet dłuższych i bardzo długich tekstów. ${ }^{9}$ Autycy powtarzaja nie tylko słowa usłyszane $\mathrm{w}$ danej chwili, ale też przypominaja je sobie, gdy stykaja się $z$ jakimś sygnałem nawiąującym w sposób werbalny lub zdarzeniowy do wcześniejszej sytuacji. Od strony poznawczej wygląda to według Uty Frith tak, że echolalia jest „wyraźnym przejawem oderwania peryferyjnych systemów przetwarzania od systemu centralnego, który zajmuje się znaczeniami”. Elementy języka przyswojone na poziomie opanowania struktury gramatycznej mowy nie mogą być zinterpretowane znaczeniowo na wyższym poziomie [Frith 2008, 155].

Nie będę bliżej analizował istoty echolalii, ponieważ kwestiami tymi zajmowałem się w oddzielnych tekstach [zob. Kominek 2014; 2020]. Opiera się ona na wyszukiwaniu w pamięci (tak jak w wyszukiwarce internetowej $\mathrm{w}$ zasobie mnóstwa połaczeń leksykalnych) skojarzeń $z$ danym słowem, najczęściej na zasadzie przyległości. Okazuje się więc, że nawet echolalia wykorzystuje kontekst językowy (gramatyczny), bazując na znajomości konwencjonalnych struktur językowych, co skutkuje łatwościa ich powtarzania. Bardziej od funkcjonowania mechanizmu „mowy za kimś” interesuje mnie problem, która funkcja językowa określa najpełniej język osób ze spektrum autyzmu.

Wymiana informacji między nadawca a odbiorca wymaga tzw. teorii umysłu, o czym pisałem wcześniej, a skoro autycy mają niewielka (albo wcale jej nie maja) kompetencję w tym zakresie, mowa nieintencjonalna nie pełni zasadniczej funkcji informacyjnej. Podobnie jest $z$ innymi funkcjami języka - tu wyróżnia się całkowity brak funkcji fatycznej czy metajęzykowej. Niektóre funkcje, takie jak emotywna i konatywna, mogłyby występować w mowie autyków, jeśli brano by pod uwagę niezamierzoną ekspresję nadawcy i wpływanie na odbiorcę, a tego R. Jakobson nie uwzględnił w swojej teorii [Grzegorczykowa 2008, 49]. Podobnie można by się doszukiwać funkcji poetyckiej, ponieważ wiele ripost echolalicznych i pseudogier językowych emanuje pozornie estetycznym skupieniem się na przekazie językowym, tylko jakby dla samego języka. Jeśli odbierzemy tym funkcjom wartość komunikacyjna, to czy język osób „mówiących za kimś” pozostanie bezmyślnym naśladowaniem innych osób i mówieniem dla samego mówienia?

9 Nawet jeśli weźmiemy pod uwagę fakt, że zarówno w normalnym rozwoju, jak i w patologii rozwojowej echolalia zanika w miarę postępów językowych dziecka, to i tak dotyczy to dużej liczby osób, które nie moga przekroczyć granicy pomiędzy złożonym procesem przetwarzania informacji a ich interpretacja na poziomie znaczeniowym. 
Osoby z autyzmem, niezależnie od miejsca zajmowanego na „linii” rozwoju, wykazuja tego samego typu stereotypie zachowan, tzn. powtarzaja uporczywie te same pytania i teksty, wirują wokół osi swojego ciała czy przestrzegają rutynowych, sztampowych rytuałów. Otóż wszystkie te zachowania sa wg Leo Kannera „solipsystycznymi formami zachowań autostymulacyjnych" [za: Silberman 2017, 181]. Za Kannerem również inni badacze mówią o echolaliach i stereotypiach językowych jako o nieuświadomionej autostymulacji. Cecha ta nasuwa skojarzenie, że podstawowa funkcja języka bez komunikacji jest funkcja autostymulacyjna. Język w tym wypadku służy w przeważającej mierze tylko tym osobom, jest zamkniętym środkiem skupienia uwagi na samym sobie. Czasami, tak jak inne zachowania autostymulacyjne, pobudza autyków do bezproduktywnej aktywności, a niekiedy stanowi bufor bezpieczeństwa wobec silnego napięcia emocjonalnego i lęku.

\section{NIEROZUMIENIE MOWY PRZENOŚNEJ}

Trzecia wyróżniona przeze mnie cecha zaburzeń poznawczych autyków wiąże się $z$ metafora i należy do najczęściej wymienianych cech. Metafora, odwołując się do dobrze przyswojonych zespołów pojęciowych, modeluje za ich pomoca obiekty, zdarzenia, zjawiska będace przedmiotem wypowiedzi o różnym charakterze. Naświetla w ten sposób pewne aspekty analizowanych zjawisk, umożliwia ich lepsze zrozumienie. Ma to niewatpliwy walor poznawczy, ponieważ ,jednym rzutem odsłania (...) cały kompleks cech i uwikłań przedmiotu, których ujawnienie wymagałoby długiego procesu analitycznego" [Dobrzyńska 1994, 202]. Ta skrótowość, dostępność, a niekiedy i niezbędność poznania przez metaforę sprawia, że wyrażenia przenośne zaliczane sa do najbardziej sugestywnych środków komunikacji.

Mówimy zagadkami i peryfrazami. Wkładamy, jak się zdaje, dużo wysiłku, by nie powiedzieć dokładnie tego, co mamy na myśli, prostymi, zwyczajnymi słowami [Dunbar 2014, 152].

U źródeł takiego rozumienia języka stoi tzw. mechanizm odłączania reprezentacji przenośnych od rzeczywistości, o czym pisałem we wprowadzeniu. Myśl odłączona, zwolniona ze zwykłego odnoszenia się do rzeczywistości, wchodzi w skład innych myśli, a jej znaczenie przechodzi zadziwiajace przemiany [Frith 2008, 110]. Dekodowanie mechanizmów przeniesienia jest umiejętnością tak prostą i oczywistą, że radzą sobie $z$ nia nawet małe dzieci. Do tej bardzo ogólnej charakterystyki istoty metafory należy dodać ważna cechę, że w myśl semantyki kognitywnej wiele metafor pojęciowych podlega swoistej „realizacji” w rzeczywistości społecznej i kulturowej, to znaczy że nie istnieją tylko i wyłącznie jako 
pojęcia i słowa, ale również jako rzeczy, procesy, zjawiska, jakie można zaobserwować w sferze praktyk społecznych i kulturowych, np. niektóre podlegają wizualizacji (taniec, malarstwo, sztuka), inne sa urzeczywistniane poprzez rytuały i zwyczaje. ${ }^{10}$

Takich umiejętności nie mają osoby $z$ autyzmem, nawet te wysokofunkcjonujące. ${ }^{11}$ Michael Tomasello zauważa, że

osoby $z$ autyzmem, które pomimo że wzrastają wśród kumulatywnych wzorców kulturowych, nie moga w pełni korzystać $z$ kolektywnej mądrości w nich zawartej, gdyż $z$ powodów biologicznych nie posiadaja koniecznych zdolności społeczno-poznawczych [Tomasello 2002, 16].

Osoby te cechuje nie tylko brak posługiwania się metaforami, ale także opaczne rozumienie takich aktów kompetencji komunikacyjno-społecznej jak kłamstwo, żart czy ironia, a także nieumiejętność udawania. Jak wykazałem to $\mathrm{w}$ innym artykule na ten temat, aktom tego rodzaju można przypisać następujące wspólne cechy: niedosłowność; tworzenie i podtrzymywanie relacji społecznych i komunikacyjnych; posiadanie przez nadawcę i odbiorcę wyższej świadomości poznawczej związanej z tzw. teorią umysłu; intencjonalność charakteryzująca się przekonaniami co najmniej drugiego rzędu; reprezentacje poznawcze tego, co ludzie zamierzaja zakomunikować odbiorcy; odłączanie reprezentacji od rzeczywistości; posiadanie zdolności oderwania się od bezpośredniego kontaktu i odniesienia się do nieistniejących w bezpośredniej bliskości zjawisk [Kominek 2018].

Nie będę dokładnie analizował znaczenia przenośnego wymienionych przykładowych aktów kompetencji komunikacyjno-społecznej. Do zagadnień związanych $z$ nierozumieniem mowy przenośnej należy problem hipotetycznego oglądu świata $z$ punktu widzenia osób autystycznych. Jeżeli poznamy dogłębnie funkcję poznawczą metafory, to zrozumiemy, jak trudno się bez niej obejść: w uczeniu się, radzeniu sobie $z$ różnymi społecznymi interakcjami, w autorefleksji towarzyszącej poznawaniu świata czy twórczym rozwiązywaniu problemów. „Życie bez metafory” jest określeniem, które powtarza się w wielu modelach kognitywnych konstruowanych w tym celu, aby lepiej zrozumieć zachowanie dzieci

$10 \mathrm{Na}$ przykład układ miejsc podczas formalnych posiedzeń w ważnych instytucjach jest odzwierciedleniem metafor pojęciowych: ZNACZACE / WAŻNE TO CENTRUM i ZNACZACE / WAŻNE TO WYSOKO OraZ ich przeciwieństwa: MNIEJ WAŻNE TO PERYFERIE oraz MNIEJ WAŻNE TO NISKO [Kövecses 2011, 213-216].

11 Bohater popularnego serialu Barwy szczęścia, emitowanego w TVP2, Kacper, który jest maturzystą świetnie radzacym sobie $z$ nauka, ale mającym problemy w sferze społecznej, prosi najbliższych, żeby nie zwracali się do niego, używając frazeologizmów, które oparte sa na mówieniu przenośnym typu: pilnować swojego nosa 'zająć się swoimi sprawami'; burza oklasków ‘dużo oklasków'; mieć serce na dłoni 'być dobrym dla kogoś’. 
oraz dorosłych osób z głębszymi zaburzeniami autystycznymi - ich teorie umysłu, problemy $z$ mentalizowaniem, deficyty w funkcjach wykonawczych, słabą spójność centralną czy niemożność kontroli uwagi wizualnej $^{12}$ [Szatmari 2007, 136].

W celu zobrazowania tego typu problemów przedstawię $-z$ konieczności w wielkim skrócie - wyjątkową relację autobiograficzną osoby $z$ autyzmem: Temple Grandin. ${ }^{13}$

$Z$ opowiadania autorki wynika, że w dzieciństwie nie rozumiała ona znaczenia przenośnego wyrazów, odbierając wszystkie komunikaty językowe dosłownie. Działo się tak do pewnego ważnego wydarzenia, które stało się przełomowe w życiu T. Grandin i uzmysłowiło jej istnienie innego świata kryjącego się pod powłoką codziennych słów. Autorka, będąc na nabożeństwie, usłyszała słowa Chrystusa, który sam o sobie powiedział: „Ja jestem bramą. Jeśli ktoś wejdzie przeze mnie, będzie zbawiony... (J 10, 9)”. Słowa o przekroczeniu bramy, czyli po prostu drzwi, są dla niej tak ekscytujacce, że postanawia je odnaleźć, koncentrując się na fizycznej stronie całego zdarzenia, i ogląda każde drzwi. Ta przygoda przybiera nieoczekiwany i symboliczny obrót, bo kończy się odkryciem przez T. Grandin drzwi na dach domu, gdzie autorka czuje się szczęśliwa i rozumie, że w jej życiu wydarzyło się coś przełomowego. Później jeszcze T. Grandin odkryje inne drzwi, które pogłębią w niej to rozumienie wykraczające poza czysto fizyczne znaczenie. ${ }^{14}$

12 O teorii umysłu pisałem już w tym opracowaniu. Teoria centralnej koherencji odnosi się do zaburzeń integracji informacji i odczytywania ich znaczenia $z$ kontekstu, teoria deficytów funkcji wykonawczych zaś tłumaczy plany czynności w celu osiagnięcia celu, które objawiaja się sztywnościa zachowania, perseweracjami, koncentracja na detalach, trudnościami w przenoszeniu uwagi i wykorzystywaniu informacji zwrotnych oraz ignorowaniem informacji nieistotnej, impulsywnością tudzież trudnościami w planowaniu i realizacji planu.

13 Temple Grandin urodziła się w 1947 r. w Bostonie w stanie Massachusetts (USA). Kiedy miała dwa lata, rozpoznano u niej autyzm. Rodzice nie zgodzili się na umieszczenie córki w zakładzie opiekuńczym, uparcie walczyli o to, aby dziecko w końcu zaczęło mówić. Dzięki wytrwałości matki T. Grandin ukończyła szkołę z internatem dla dzieci uzdolnionych. Następnie uczęszczała do Franklin Pierce College, gdzie zdobyła tytuł licencjata $z$ psychologii. Edukację kontynuowała na Arizona State University, uzyskując tytuł magistra zoologii, a następnie obroniła doktorat $z$ psychofizjologii zwierząt na University of Illinois. Obecnie Temple Grandin jest profesorem Colorado State University, zajmuje się optymalizacją budynków i urządzeń dla farm hodowlanych, współpracuje $z$ czasopismami naukowymi związanymi $z$ jej specjalizacją $i$ wygłasza referaty na konferencjach w całym kraju. W swojej analizie wykorzystam materiał źródłowy pochodzacy z książki autobiograficznej Temple Grandin Byłam dzieckiem autystycznym [1995].

14 Pełny opis tej metafory i próbę jej zrozumienia, zawartą w relacji autobiograficznej T. Grandin, można znaleźć w artykule: Kominek 2013. 
To po prostu szklane drzwi. A jednak - bariera. Domyślam się, że ich znaczenie zawiera się $\mathrm{w}$ dwóch sekundach potrzebnych na przejście przez nie - jak na przejście $z$ jednego stanu umysłu do drugiego - napisała w swoich wspomnieniach [Grandin 1995, 88].

Starając się zrozumieć, jak wyglądałby świat bez metafory, oparłem się na trzech typach metafor, realizujących różne cele poznawcze: metaforach strukturalnych, ontologicznych i orientacyjnych. ${ }^{15}$ Metafory te są, ogólnie mówiąc, niezbędne w efektywnym uczeniu się, radzeniu sobie $z$ różnymi społecznymi interakcjami, w autorefleksji towarzyszacej poznawaniu świata czy twórczym rozwiazywaniu problemów. Zasadniczo wiedza na temat świata przybiera dwie formy: zawartej w sadach wiedzy deklaratywnej, która pozyskujemy ze znaczenia zdań, jakich używamy do opisania różnych zjawisk (metafory strukturalne) i wiedzy schematyczno-wyobrażeniowej, której źródłem jest powtarzające się, regularnie zachodzące doświadczanie świata (metafory ontologiczne i orientacyjne). Osoby $z$ lekkimi zaburzeniami autystycznymi moga zdobywać i porząkować wiedzę o świecie, wykorzystując w różnym stopniu tę dwojaką naturę metafor. Wprowadzone określenie życie bez metafory implikuje jednak taką sytuację poznawcza, kiedy na skutek braków biologicznych i kulturowych osoby $z$ autyzmem pozbawione sa tych zdolności poznawczych. Przywołana metafora przechodzenia przez drzwi, symbolizująca wolność, szczęście, ale także ucieczkę spod kontroli dorosłych, dojrzewanie, a także kontakt $z$ innymi ludźmi, opiera się na wiedzy schematyczno-wyobrażeniowej, która wynika $z$ cielesnego, prekonceptualnego doświadczania świata. Jak widać z relacji autorki ksiażki Byłam dzieckiem autystycznym, wielkie metafory, które sa pewnego rodzaju obsesja, ułatwiają dojrzewanie, rozwijaja myślenie, porzadkuja emocje i maja wartość terapeutyczną. Często nadmierny stres i pobudzenie muszą być porzadkowane przez zachowania autostymulujące (np. rutynowe powtarzanie jakichś czynności, włączanie i wyłączanie światła, bezcelową i bezproduktywną manipulację różnymi przedmiotami), które można odczytywać jako pozajęzykowe urzeczywistnianie się metafor.

15 W metaforach strukturalnych domena źródłowa nakłada na domenę docelową określona strukturę metaforyczną za pośrednictwem odwzorowań, które określają metaforę, np. ŻYCIE TO PODRÓż, MIŁOŚĆ TO OGIEŃ; metafory ontologiczne sprawiaja, że nieuchwytne zjawiska, procesy, działania, stany itp. stają się metaforycznymi „rzeczami”, np.: UMYSE TO MASZYNA, INFLACJA TO RZECZ, GRUPY SPOŁECZNE TO POJEMNIKI; metafory orientacyjne $z$ kolei nadaja strukturę przestrzeni fizycznej dużej części systemu pojęciowego, np. zdrowie, moralność, racjonalność, świadomość i opanowanie sa dobrymi „rzeczami”, a więc wszystkie będa zorientowane w GÓRE, podczas gdy ich przeciwieństwa sa zorientowane w DÓŁ [Lakoff, Johnson 1988; Kövecses 2011, 194]. 


\section{ROLA METONIMII I METONIMICZNY STYL POZNAWCZY}

Zastanawiając się nad brakiem rozumienia metafory i innych zjawisk pokrewnych u osób $z$ autyzmem, dostrzegłem, że działa w ich języku, podobnie jak u wszystkich ludzi tzw. neurotypowych, w sposób prawidłowy inne, ważne poznawczo narzędzie, którym jest metonimia. ${ }^{16}$ Takie ujęcie jednobiegunowe prezentuja też prace $z$ zakresu autystologii, w których mówi się o zaburzeniach podobieństwa, ale i tu akcent położony jest na metaforę (dokładniej na „życie bez metafory”). Zadaniem więc badacza jest pokazanie ujęcia faktycznie jednobiegunowego (jak wygląda świat bez metafory), ale akcentującego zachowanie mechanizmu przyległości (obraz świata rzeczy i dosłowności), który odgrywa istotna rolę w autyzmie. Autorka jednej z poczytnych książek o autyzmie, Hilde De Clercq, lubi dzielić się wspomnieniem, gdy jechała $z$ synem na wycieczkę. Pytała go kilkakrotnie, czy na pewno wzią walizkę. Thomas odpowiadał, zgodnie $z$ prawda, że tak. Po przybyciu na miejsce okazało się, że walizka jest pusta. Syn potraktował dosłownie słowo walizka jako rekwizyt związany $z$ podróżą, a nie zawartość walizki (nie przyszło mu do głowy, że rzeczy potrzebne na wyjazd, przenoszone w walizce, sa ważniejsze niż sama walizka). W przykładzie tym zawarta jest metonimia: WALIZKA ZA ZAWARTOŚć WALIZKI [Clercq 2007]. Być może w przykładach tego typu chodzi o głębszą relację KONKRET ZA ABSTRAKCJE, ponieważ osoby ze spektrum autyzmu nie rozumieja i nie używają pojęć abstrakcyjnych. Wybór nośnika metonimicznego jest zatem motywowany czynnikami komunikacyjnymi i kognitywnymi.

Stosowane w komunikacji językowej preferencje poznawcze determinowane sa doświadczeniem fizycznym i kulturowym oraz selektywnością percepcyjna [Pietrzak-Porwisz 2006, 31; por. Radden, Kövecses 1999, 44-50].

16 O ile metafora jest ujmowana jako „zasadniczo pojmowanie jednej rzeczy w terminach innej, a jej podstawowa funkcja jest zrozumienie”, o tyle „metonimia pełni głównie funkcję desygnacyjna, co pozwala nam używać pewnego pojęcia tak, aby zastapiło inne" [Lakoff, Johnson 1988, 59]. John R. Taylor [2001, 173] wyjaśnia, że metonimia jest figura stylistyczna, która polega na wykorzystaniu nazwy jednej rzeczy do oznaczania innej, przyległej rzeczy. Często obraz konkretnej rzeczy lub osoby, czy danego miejsca, zostaje przywołany w naszej pamięci za pomocą drobnego bodźca (np. związanego $z$ częścia ciała, ubraniem, materiałem), który jest uchwycony przez któryś z naszych zmysłów, a następnie przekazany do mózgu. Natomiast Zoltán Kövecses wyróżnia nośnik i element docelowy, które służą mu do wyjaśnienia, że metonimia jest procesem poznawczym, gdzie element pojęciowy, czyli obiekt (rzecz, zdarzenie, właściwość), nazywany nośnikiem, zapewnia mentalny dostęp do innego elementu pojęciowego, czyli obiektu (rzeczy, zdarzenia, właściwości), który określamy mianem elementu docelowego [Kövecses 2011, 154]. 
Obserwacja aktywności nazewniczej osób ze spektrum autyzmu pozwala na wyodrębnienie jeszcze innych preferencji kognitywnych, którymi się one kierują. Oprócz najbardziej oczywistej ogólnej strategii kognitywnego wyróżnienia KONKRET $\rightarrow$ ABSTRAKCJA, stosowane są również inne strategie, bardziej szczegółowe: CZĘŚĆ $\rightarrow$ CAŁOŚĆ, BLISKOŚĆ $\rightarrow$ DALEKOŚĆ, SKRÓTOWOŚĆ $\rightarrow$ KOMPLEMENTARNOŚĆ, WIZUALNOŚĆ $\rightarrow$ WERBALNOŚĆ.

W normalnym użyciu języka chodzi o dychotomiczny charakter mechanizmu poznawczego człowieka, składającego się $z$ metafory i metonimii. Podbudowę tej teorii stanowi żywotna i niezwykle kreacyjna teoria Romana Jakobsona, który sześćdziesiąt lat temu zwrócił uwage na istnienie dwóch odrębnych stylów poznawczych, będących realizacjami zwykłego kodu i tzw. inferencji, związanych $z$ możliwością rozwijania wszelkich rodzajów dyskursów za pomoca dwóch „linii semantycznych”, gdzie jeden temat wiaże się $z$ drugim albo przez podobieństwo (metafora), albo przez przyległość (metonimia) [Jakobson 1989a].

Teorię tę rozwinał $\mathrm{R}$. Jakobson na podstawie spostrzeżeń zwiąanych $z$ dwoma typami zakłóceń afatycznych. Wychodzi on od stwierdzenia, że zakłócenia mowy moga zmniejszyć zdolność człowieka do kombinowania bądź zdolność do selekcji jednostek językowych. ${ }^{17} \mathrm{R}$. Jakobson bardzo dokładnie i wszechstronnie analizuje przykłady językowe świadczące o tych rodzajach zakłóceń afatycznych, by na końcu stwierdzić, że chociaż odmiany afazji są liczne i różne, to wszystkie mieszczą się między dwoma biegunowymi typami, tzn. każda forma zakłócenia afatycznego polega na jakimś mniejszym lub większym upośledzeniu albo zdolności do selekcji i substytucji, albo zdolności do kombinacji i budowania kontekstu. W pierwszym typie afazji ginie stosunek podobieństwa, w drugim - stosunek przyległości. „Metafora jest obca zakłóceniu w dziedzinie podobieństwa, a metonimia - zakłóceniu w dziedzinie przyległości” - konkluduje R. Jakobson [1989a, 169].

Uważna lektura Jakobsonowskich spostrzeżeń na temat zakłóceń $\mathrm{w}$ dziedzinie podobieństwa, zbieżnych $z$ jednym $z$ dwóch rodzajów afazji, naprowadza wnikliwego badacza na szereg takich samych cech w sposobie posługiwania się językiem w autyzmie, a zwłaszcza dotyczących działania i roli kontekstu $^{18} \mathrm{w}$ tekście. Dla autyka kontekst jest czynnikiem niezbędnym

17 Według uczonego w każdym znaku językowym działaja dwa rodzaje układu: 1) kombinacja, gdzie każdy znak jest złożony ze znaków składowych i/lub występuje tylko w kombinacji z innymi znakami; 2) selekcja, tzn. wybór spośród alternatyw implikuje możliwość zastapienia jednej druga, równoważną pierwszej pod jednym względem, a różną od niej pod innym względem. Składniki kontekstu sa w stanie styczności, podczas gdy w serii alternacyjnej znaki sa połączone przez różne stopnie podobieństwa [Jakobson 1989a, 154-155].

18 Termin kontekst, używany na gruncie językoznawstwa i teorii tekstu, ma dwa znaczenia - wiąże się $z$ otoczeniem językowym bądź sytuacyjnym. Kontekst językowy (gramatyczny) to element lub zespół elementów sąsiadujących w wypowiedzeniu $z$ dana jednostką (fonemem, morfemem, wyrazem, składnikiem, zda- 
i decydującym. Im bardziej jego wypowiedzi zależą od kontekstu, tym lepiej daje on sobie radę $z$ używaniem języka. „Im silniej wypowiedź opiera się na kontekście lub konsytuacji, tym większe jest prawdopodobieństwo, że pacjent tego rodzaju da sobie radę" [Jakobson 1989a, 157]. Jakobsona przede wszystkim interesuje pierwszy typ kontekstu (gramatyczny), ten który decyduje o zachowaniu relacji styczności, kiedy ginie relacja podobieństwa, która wymaga umiejętności posługiwania się składnikami konsytuacyjnymi. Komunikacja językowa uwzględniająca tylko ten typ kontekstu jest powierzchowna, zdeterminowana czynnikami gramatycznymi, nastawiona na tworzenie zdań i wypowiedzi, często będących minimalnymi połączeniami jednostek językowych. Opiera się ona na znajomości konwencjonalnych struktur językowych, która skutkuje łatwością ich powtarzania. Im bardziej wyraz zależy od innych wyrazów tego samego zdania i im bardziej bezpośrednio odnosi się do kontekstu składniowego, tym mniej jest dotknięty przez zakłócenie. Struktury te, chociaż poprawne pod względem gramatycznym, rażą sztucznością, zbytnią ogólnością i nie pasują do odrębnych i innych za każdym razem zdarzeń komunikacyjnych.

Ważnym wyróżnikiem opisywanego mechanizmu jest fakt, że sam R. Jakobson mówił o dwóch stylach poznawczych, ${ }^{19}$ mających o wiele szerszy kontekst: stylu metaforycznym i metonimicznym, nawiązując do poglądów głoszonych na gruncie psychologii poznawczej i wyprzedzając idee lingwistyki kognitywnej. Same nazwy sugerują korelację między rozumieniem tego zjawiska na gruncie zjawisk językowych i pozajęzy-

niem). Kontekst sytuacyjny (konsytuacja) uwzględnia warunki, w których odbywa się dany akt mówienia, np. miejsce i czas, przynależność społeczna jego uczestników, relację między nadawcą a odbiorca itd. [Urbańczyk (red.), 168-169].

19 Styl poznawczy to termin wprowadzony przez Hermana A. Witkina, który zdefiniował style poznawcze jako charakterystyczne dla poszczególnych jednostek stałe sposoby funkcjonowania w zakresie czynności poznawczych i intelektualnych [Matczak 1982, 11]. Oznaczają one według Witkina indywidualne różnice w zakresie procesów poznawczych zwiazanych $z$ odzwierciedlaniem otoczenia. Badacz ten podzielił ludzi na dwie grupy w zależności od tego, czy przedstawiaja otoczenie w sposób globalny, uzależniony od kontekstu („zależni od pola”), czy raczej w sposób zróżnicowany, analityczny („niezależni od pola”). Niezależny od pola styl poznawczy to tendencja do kierowania się w percepcji głównie wskazówkami wewnętrznymi, styl zależny od pola to tendencja do kierowania się w większym stopniu wskazówkami zewnętrznymi. Psychologowie nazywaja je także odpowiednio tendencyjnościa lokalna i tendencyjnościa globalna [Grandin, Panek 2016, 163-169]. Uta Frith wprowadziła jeszcze inne pojęcie - tzw. koherencji centralnej (weak central coherence theory), którą rozumie jako siłę scalajacca wiele informacji. Silna koherencja centralna może wpływać na słabe wyodrębnianie figur ukrytych na rysunku. $Z$ kolei słaba koherencja centralna może tłumaczyć dobre radzenie sobie $z$ tym zadaniem [Frith 2008, 187-205]. W sposób obrazowy można powiedzieć, że słaba koherencja centralna oznacza niedostrzeganie lasu, gdy patrzy się na drzewa, a silna koherencja centralna - niedostrzeganie drzew, gdy patrzy się na las [Frith 2008, 190; Grandin, Panek 2016, 166]. 
kowych, takich jak np. poezja i proza, percepcja świata zmysłowego, tworzenie świata emocji i estetyki, a więc i w różnego rodzaju sztuce: malarstwie, fotografice lub filmie, wyznaczając centralne miejsce metaforze (i metonimii), od których biora swój wyróżnik.

Zgodnie $z$ teoria tzw. centralnej koherencji osoby ze spektrum autyzmu nie potrafia generalizować, uspójniać, dostrzegać podobieństw. Ich świat jest zatomizowany, pokawałkowany, podlega dosłowności. „Fragmenty radza sobie $z$ genialnym rozdrobnieniem, gdzie normalne myślenie jest bez szans" - napisała jedna $z$ osób dotkniętych autyzmem. I chociaż osoby te $z$ niezwykłą łatwością rozwiązują różne układanki, to badania pokazuja, że gdyby na puzzlach nie było obrazków, one ułożyłyby je, dopasowując sam kształt brzegów poszczególnych kawałków układanki. Być może osoba autystyczna w ułożonej już układance nadal widzi poszczególne elementy. Brak wpływu kontekstu, brak uchwycenia głębszego znaczenia jest dowodem na słaba koherencję centralną [por. Frith 2008, 187-205].

Innym ważnym wyróżnikiem stylów poznawczych jest rozróżnianie - według Simona Barona-Cohena - nie tylko zdolności rozpoznawania myśli lub uczuć innej osoby, ale także reagowanie na jej myśli i uczucia odpowiednia emocja [Baron-Cohen 2015, 32]. Od słowa empatia został nazwany ten zbiór charakterystycznych cech empatyzowaniem, który przeciwstawił S. Baron-Cohen systematyzowaniu. ${ }^{20}$ Ma to odzwierciedlenie w dwóch stylach poznawczych: pierwszym, opartym na zainteresowaniu światem stanów mentalnych i uczuciowych ludzi, i drugim, zwiazanym $z$ przetwarzaniem informacji dotyczacych różnych struktur, a więc światem rzeczy [zob. Frith 2008, 200-201]. Osoby $z$ autyzmem zamiast myśleć o innych ludziach, co im powiedzieć i co należy im powiedzieć, myślą o rzeczach, które nie wymagają znajomości teorii umysłu i nie są tak skomplikowane jak osoby. Myślenie takie cechuje dosłowność, naiwność, odtwarzalność i powtarzalność. „W takim stanie - jak pisze S. Baron-Cohen - wchodzimy w kontakt wyłącznie $z$ przedmiotami albo $z$ ludźmi traktowanymi jak przedmioty" [Baron-Cohen 2015, 24]. Ludzie $z$ autyzmem wybieraja towarzystwo świata rzeczy bardziej niż ludzi dlatego, że świata społecznego nie rozumieja. $Z$ rzeczami nie trzeba rozmawiać, patrzeć im w twarz, unikać kłopotliwych spojrzeń. Chłopak z zespołem Aspergera zapytany, dlaczego się nie ożenił, odpowiada, że małżeństwo jest zbyt skomplikowane. Gorzej jest, kiedy traktowanie ludzi w sposób przedmiotowy niesie ze sobą zjawiska nieprzyjemne i wręcz niebezpieczne, jakby osoby ze spektrum autyzmu nie odróżniały ludzi od przedmiotów. Każdy rodzic lub osoba na co dzień zajmująca się autykami znaja doskonale uczucie, kiedy stają się po prostu „uniwersalnymi automatami $z$ dobrami Matki Natury, wielkim przyciskiem zapewniającym zaspokojenie wszelkich pragnieñ" [Baron-Cohen 2015, 113]. ${ }^{21}$

20 Można się spotkać również z określeniem systemizowanie.

21 Więcej na temat metonimicznego stylu poznawczego zob. Kominek 2018. 


\section{PODSUMOWANIE}

W przedstawionym artykule starałem się pokazać najistotniejsze moim zdaniem cechy języka osób $z$ autyzmem jako bezpośrednio wynikające $z$ zaburzonych bądź całkiem inaczej przebiegajacych procesów poznawczych zachodzacych w ich umysłach. Za zakłócenia uważam posługiwanie się mową nieautonomiczna, kopiowaną i nieintencjonalną oraz nierozumienie znaczeń przenośnych w języku. Pozytywny aspekt można natomiast dostrzec w idiolektalnym obrazie ich świata, który mimo modyfikacji jest mniej lub więcej osadzony w ogólnym językowym obrazie świata, oraz w metonimicznym stylu poznawczym, wykorzystującym potencjał umiejętności tzw. systematyzowania. Zjawiska negatywne wpływaja zapewne na percepcję autyków jako osób dziwnych, wyizolowanych i nierozumianych przez innych. Zjawiska pozytywne natomiast pozwalają mówić o osobach $z$ autyzmem nie jako zaburzonych, ale neuroróżnorodnych, a to oznacza niesamowity skok jakościowy w ocenie ich rozwoju i zdolności poznawczych. Mimo to język autyków traktuję jako język bez-myślny, nawiązując do braku podstawowej umiejętności poznawczej, która jest świadomość swoich i cudzych aktów mentalnych, czyli znajomości teorii umysłu. Umiejętność ta pozwoliła w rozwoju filogenetycznym gatunku ludzkiego na współpracę i uspołecznienie, a ontogenetyczny poziom rozwoju autyków przypomina niestety okres wcześniejszy, kiedy praludzie nie potrafili ze sobą współpracować i dążyć razem do postępu cywilizacyjnego.

\section{Bibliografia}

J. Aitchison, 2002, Ziarna mowy. Początki i rozwój języka, Warszawa.

J. Antczak-Sokołowska, 2017, Idiolektalny obraz świata chłopca z autyzmem na przykładzie nazw zwierzat [w:] B. Szejgiec, D. Gocół (red.), Subiektywizm w języku, Lublin, s. 9-16.

J. Bartmiński, 2012, Językowe podstawy obrazu świata, Lublin.

B.K. Bergen, 2018, Latajace świnie. Jak umysł tworzy znaczenie, Kraków.

S. Baron-Cohen, 2015, Teoria zła. O empatii i genezie okrucieństwa, Sopot.

J.L. Borges, 1972, Pamiętliwy Funes [w:] J.L. Borges, Fikcje, Warszawa, s. 95-98.

H. De Clerq, 2007, Autyzm od wewnatrz. Przewodnik, Warszawa.

T. Dobrzyńska, 1994, Mówiąc przenośnie... Studia o metaforze, Warszawa.

R. Dunbar, 2014, Nowa historia ewolucji człowieka, Kraków.

R. Dunbar, 2017, Pchły, plotki a ewolucja człowieka. Dlaczego człowiek zaczą mówić?, Kraków.

D.L. Everett, 2019, Jak powstał język. Historia największego wynalazku ludzkości, Warszawa.

U. Frith, 2008, Autyzm. Wyjaśnienie tajemnicy, Gdańsk.

T. Grandin, R. Panek, 2016, Mózg autystyczny. Podróż w głąb niezwykłych umysłów, Kraków.

T. Grandin, M.M. Scariano, 1995, Byłam dzieckiem autystycznym, WarszawaWrocław. 
R. Grzegorczykowa, 2008, Wstepp do językoznawstwa, Warszawa.

R. Jakobson, 1989a, Dwa aspekty języka i dwa typy zakłóceń afatycznych [w:] R. Jakobson, W poszukiwaniu istoty języka, t. 1: Wybór pism, wybór, red. nauk. i wstęp M.R. Mayenowa, Warszawa, s. 150-175.

R. Jakobson, 1989b, Poetyka w świetle językoznawstwa [w:] R. Jakobson, W poszukiwaniu istoty języka, t. 2, Wybór pism, wybór, red. nauk. i wstęp M.R. Mayenowa, Warszawa, s. 77-124.

A. Kominek, 2013, Jak wygladałby świat bez metafory? Próba opisu sytuacji poznawczej osób z autyzmem na podstawie założen językoznawstwa kognitywnego [w:] E. Boksa, A. Michalska, P. Zbróg (red.), Aktualne problemy diagnozy $i$ terapii osób z niepełnosprawnościami sprzężonymi i zaburzeniami rozwojowymi, Kraków, s. 69-86.

A. Kominek, 2014, Zakłócenia $w$ dziedzinie podobieństwa $w$ komunikacji językowej osób z autyzmem - i co z tego wynika, „LingVaria” nr 2, s. 55-68.

A. Kominek, 2018, Co wspólnego ma metafora z kłamstwem, żartem i udawaniem?, „LingVaria” nr 2, s. 25-38.

A. Kominek, 2020, „Mówienie za kimś” jako język bez komunikacji, „LingVaria” nr 2, s. 135-148.

M. Korendo, 2013, Językowa interpretacja świata w wypowiedziach osób z zespołem Aspergera, Kraków.

A. Kozłowska, 2009, Problemy z idiolektem [w:] T. Korpysz, A. Kozłowska (red.), Jezzyk pisarzy jako problem lingwistyki, t. 2, Warszawa, s. 111-131.

Z. Kövecses, 2011, Jezyk, umyst, kultura. Praktyczne wprowadzenie, Kraków.

G. Lakoff, M. Johnson, 1988, Metafory w naszym życiu, Warszawa.

B. Malinowski, 1987, Ogrody koralowe $i$ ich magia. Język magii $i$ ogrodnictwa, Warszawa.

A. Matczak, 1982, Style poznawcze, Warszawa.

W. Myśliwski, 2018, Ucho igielne, Kraków.

G. Pietrzak-Porwisz, 2006, Metonimia w ujęciu kognitywnym, „Prace Językoznawcze" UWM, z. VIII, Olsztyn, s. 29-39.

G. Radden, Z. Kövecses, 1999, Towards a Theory of Metonymy [w:] K.U. Panther, G. Radden (red.), Metonymy in Language and Thought, Amsterdam-Philadelphia, s. 17-60.

S. Silberman, 2017, Neuroplemiona. Dziedzictwo autyzmu i przyszłość neuroróżnorodności, Białystok.

P. Szatmari, 2007, Uwięziony umysł. Opowieści o ludziach z autyzmem, Kraków.

J.R. Taylor, 2001, Kategoryzacja w języku. Prototypy w teorii językoznawczej, Kraków.

K. Termińska, 1991, O pewnej nie nazwanej funkcji języka (na przykładzie usprawiedliwień) [w:] J. Bartmiński, R. Grzegorczykowa (red.), Język a kultura, t. 4: Funkcje języka i wypowiedzi, Wrocław, s. 65-72.

M. Tomasello, 2002, Kulturowe źródła ludzkiego poznania, Warszawa.

S. Urbańczyk (red.), 1991, Encyklopedia języka polskiego, Wrocław. 


\section{A thoughtless language. Disruptions of cognitive phenomena in autistic people}

\section{Summary}

In the presented paper, I am making an attempt to demonstrate the most important, in my opinion, characteristics of the language used by people with autism as ones arising directly from disrupted or completely different cognitive processes taking place in their minds. Such individuals lack, in the first place, the fundamental cognitive skill being the awareness of their own and other people's mental acts. The absence or insufficiency of the theory of mind gives rise to disorders in acquiring the linguistic worldview, inability to decode figurative meanings, failure to use langue in order to maintain contact, and failure to speak of language itself, and many more. Autistic people are characterised by the metonymic cognitive style, which uses the potential of the so-called systemising skills. Instead of thinking of other people, what to say to them and what should be said to them, people with autism think of the things that do not require familiarity with the theory of mind and are not as complex as humans.

Keywords: autism - theory of mind - idiolectal worldview - language functions - metaphor - metonymic cognitive style

Trans. Monika Czarnecka 